\title{
Correction equations to estimate body fat with plicometer WCS dual hand
}

\author{
Hiago Augusto Zonatto ${ }^{*}$, Marcelo Romanovitch Ribas², Eduardo Bolicenha Simm³, \\ André Gonçalves de Oliveira ${ }^{2}$, Julio Cesar Bassan ${ }^{4}$ \\ ${ }^{I}$ Graduate Program of Biomedical Engineering, Federal Technological University of Paraná, Curitiba, PR, Brazil. \\ ${ }^{2}$ Laboratory of Physiology and Biochemistry, Dom Bosco College, Curitiba, PR, Brazil. \\ ${ }^{3}$ Autonomous University Center of Brazil, Curitiba, PR, Brazil. \\ ${ }^{4}$ Densitometry Laboratory, Federal Technological University of Paraná, Curitiba, PR, Brazil.
}

\begin{abstract}
Introduction: This study aimed to propose regression equations for the correction of fat percentage values obtained with the WCS Dual Hand skinfold caliper, using the Lange skinfold caliper as a reference. Methods: This study evaluated 112 undergraduate students from the Physical Education and Physical Therapy programs of the Faculdade Dom Bosco, located in Curitiba, Paraná, Brazil. Of these, 58 women were $24.9 \pm 5.8$ years old and 54 men were $27.6 \pm 7.9$ years old. The evaluation comprised the following measurements: height, body mass, and nine skin folds with WCS Dual Hand and Lange skinfold calipers used in biceps, triceps, subscapular, suprailiac, pectoral, average axillary, medial thigh, abdominal, and calf measurements. Results: Through the simple linear regression analysis, eight equations were generated to correct the relative body fat obtained with equations commonly used in Brazil. For these correction equations, $\mathrm{R}^{2}$ was between 0.830 and 0.961 and $\mathrm{p}$-value was 0.000 for all measurements. Conclusion: These results indicate the use of equations for the correction of estimated values of relative body fat measured with the WCS Dual Hand skinfold caliper, whenever the Lange skinfold caliper is not available, in order to minimize the difference between them.
\end{abstract}

Keywords Validation, Skinfold caliper, Body composition.

\section{Introduction}

Body composition can be estimated using different methods, which is extremely important for the diagnosis of the nutritional state and health (Guedes, 2013; Heyward, 2001) not only of athletes, but also of physically active and sedentary individuals (Sundgot-Borgen et al., 2013; Souza et al., 2014). Therefore, it is necessary to know the limitations and the validity of each of these methods to make sure they provide reliable data, thus ensuring proper data interpretation (Rezende et al., 2007).

Different methods to estimate the main components of the human body, lean mass and fat mass (Carvalho and Pires, 1999) are available, such as hydrostatic weighing

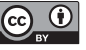

This is an Open Access article distributed under the terms of the Creative Commons Attribution License, which permits unrestricted use, distribution, and reproduction in any medium, provided the original work is properly cited.

How to cite this article: Zonatto HA, Ribas MR, Simm EB, Oliveira AG, Bassan JC. Correction equations to estimate body fat with plicometer WCS dual hand. Res Biomed Eng. 2017; 33(4):285-292. DOI: $10.1590 / 2446-4740.01117$.

*Corresponding author: Faculdade Dom Bosco, Laboratório de Fisiologia e Bioquímica, Rua Paulo Martins, n 298, Mercês, CEP 80710-010, Curitiba, PR, Brazil. E-mail: haztto@yahoo.com.br Received: 24 February 2017 / Accepted: 24 August 2017 and absorption of dual x-ray emission (DXA), which is considered the gold standard to determine body composition, bioelectrical impedance analysis, and measurement through skin folds (SF), this being the most frequent method due to its low cost (Rodrigues et al., 2001).

Regarding the skin fold method, its validity lies in the fact that much of the body fat is located in the subcutaneous tissue. Thus, by measuring the skin thickness of certain regions of the body through already existing predictive equations, it is possible to estimate the body density, and consequently, the relative fat percentage of an individual (Guedes, 2006).

However, it is important to point out that factors such as the rater's experience with the instrument, inter-rater difference, skin thickness, amount of subcutaneous fat, compressibility of the adipose tissue, and the hydration level of the evaluated subject are critical to obtain the values of body density through skin folds (Conterato and Vieira, 2001).

The predictive equations were developed by researchers who confirmed a relevant mathematical relationship between total body fat and subcutaneous fat. According to Okano et al. (2008), most predictive equations used in Brazil were developed and validated 
with the Lange skinfold caliper. When using other brands of skinfold calipers, the reliability of the equations can be compromised. Brazilian scientists tend to use the Cescorf compass in their studies, because this skinfold caliper is manufactured in Brazil (Cyrino et al., 2003). Therefore, this study aims to validate the use of a new skinfold caliper, manufactured in Brazil, with equations for the correction of body fat values, using the Lange skinfold caliper as a reference.

\section{Methods}

This is a descriptive experimental study that aims to describe the characteristics of a certain population using standardized techniques to collect data (Gil, 2002).

This study evaluated 112 undergraduate students, mean age $26.2 \pm 6.8$ years, of Caucasian ethnicity, from the Physical Education and Physical Therapy programs; of these, 54 were male, mean age $27.6 \pm 7.9$ years, and 58 were female, mean age $24.9 \pm 5.8$ years. This study included undergraduates of the following characteristics: (1) both sexes, aged 18 to 51 years; (2) hydrated individuals; (3) who had not performed vigorous exercises 24 hours before the anthropometric evaluation.

The following students were excluded from the study: (1) who presented a body mass index (BMI) equal to or greater than $30 \mathrm{~kg} / \mathrm{m}^{2}$; (2) women with waist circumference (WC) equal to or greater than $88 \mathrm{~cm}$; (3) men with waist circumference equal to or greater than $102 \mathrm{~cm}$. All participants, after being informed of the procedures to which they would be submitted, signed an informed consent form (ICF). After that, data were collected on prescheduled days by only one rater with experience of approximately three years in these types of measurements. This study was approved by the Research Ethics Committee under protocol n ${ }^{\circ} 889.026$.

\section{Anthropometric assessment}

The anthropometric assessment consisted of the following measurements: total body mass (TBM), total height (TH), biceps skin folds (BSF), triceps skin folds (TSF), subscapular skin folds (SSF), pectoral skin folds (PSF), average axillary skin folds (AASF), suprailiac skin folds (SISF), abdominal skin folds (ASF), medial thigh skin folds (MTSF), and calf skin folds (CSF). TBM was measured in an anthropometric scale, platform style (Filizola ${ }^{\circledR}$, Filizola SA, Brazil), 100 gram precision, and TH was measured with a portable stadiometer (Seca ${ }^{\circledR}$, Hamburg, Germany) of $0.1 \mathrm{~cm}$ accuracy, considering the arithmetic average of three consecutive measurements as the final value, according to the protocol of Lohman et al. (1988).

The skin folds were measured in the following order: BSF, TSF, SSF, PSF, AASF, SISF, ASF, MTSF and CSF, using two different compasses: Lange ${ }^{\circledR}$, Beta Technology Incorporated, Cambridge, USA, of $1 \mathrm{~mm}$ precision, $60 \mathrm{~mm}$ reading range, $10 \mathrm{~g} / \mathrm{mm}^{2}$ pressure, and $3 \mathrm{~mm}^{2}$ contact area; and WSC Dual Hand Cardiomed skinfold caliper, of $1 \mathrm{~mm}$ precision, $80 \mathrm{~mm}$ reading range, $10 \mathrm{~g} / \mathrm{mm}^{2}$ pressure, and $5 \mathrm{~mm}^{2}$ contact area. The WCS Dual Hand skinfold caliper offers a differentiation when compared to the other products in the market: you can read both sides of the skinfold caliper, allowing the use by left-handed people. Each skin fold was measured three times with both skinfold calipers in every evaluated person, from from the right hemibody, and the final result was the arithmetic average of the measurements. It should be emphasized that the instruments used in the research are properly calibrated according to their respective resolutions at the Cardiomed Company Ltda, Curitiba, Paraná - Brazil (attachments 1,2). Instrument calibration is a concern to ensure higher accuracy in the measurements, according to Perini et al. (2005) and Melo et al. (2012). At the end of each sequence, the rater changed the adipometers. From the values of the skin folds, the body density was estimated using the predictive equations proposed by Jackson and Pollock (1978), Jackson et al. (1980), Durnin and Womersley (1974), and Petroski (1995). The relative body fat was estimated from the equation proposed by Siri (1956).

Jackson and Pollock (1978), equation for men, 3 skin folds:

$$
\begin{aligned}
& D=1.1093800-(0.0008267 *(A S F+P S F+M T S F))+ \\
& 0.0000016 *\left((A S F+P S F+M T S F)^{2}\right)-(0.0002574 *(A g e))
\end{aligned}
$$

Jackson et al. (1980), equation for women, 3 skin folds:

$$
\begin{aligned}
& D=1.21389-(0.04057 \log (T S F+S I S F+M T S F))- \\
& \left(0.00016^{*}(\text { Age })\right)
\end{aligned}
$$

Jackson and Pollock (1978), equation for men, 7 skin folds:

$$
\begin{aligned}
& D=1,112-\left(0,00043499 *\left(\sum 7 S F\right)\right)+0,00000055 * \\
& \left(\left(\sum 7 S F\right)^{2}\right)-(0,00028826 *(\text { Age }))
\end{aligned}
$$

Jackson et al. (1980), equation for women, 7 skin folds:

$$
\begin{aligned}
& D=1.097-\left(0.00046971 *\left(\sum 7 S F\right)\right)+(0.00000056 * \\
& \left(\left(\sum 7 S F\right)^{2}\right)-(0.00012828 *(\text { Age }))
\end{aligned}
$$

Durnin and Womersley (1974), equation for men:

$$
D=1.1765-(0.774(\log T S F+S I S F+S S F+B S F))
$$

Durnin and Womersley (1974), equation for women: 


$$
D=1.1567-(0.0717(\log T S F+S I S F+S S F+B S F))
$$

Petroski (1995), equation for men:

$$
\begin{aligned}
& D=1.10726863-(0.00081201(S S F+T S F+S I S F+C S F))+ \\
& 0.00000212(S S F+T S F+S I S F+C S F)^{2}-(0.00041761(\text { Age }))
\end{aligned}
$$

Petroski (1995), equation for women:

$$
\begin{aligned}
& D=1.19547130-(0.07513507 * \log (A A S F+S I S F+M T S F+C S F))- \\
& (0.00041072(\text { Age }))
\end{aligned}
$$

The percentage of body fat $(\% \mathrm{BF})$ of the all equations will be obtained by Siri (1956):

$\% B F=(495 / D)-450$

were, $\mathrm{D}=$ Density; $\mathrm{BSF}=$ biceps skin fold; $\mathrm{TSF}=$ triceps skin fold; SSF = subscapular skin fold; PSF = pectoral skin fold; AASF = average axillary skin fold; SISF = suprailiac skin fold; ASF = abdominal skin fold; MTSF = medial thigh skin fold; $\mathrm{CSF}=$ calf skin fold; $\Sigma 7 \mathrm{SF}=\mathrm{Sum}$ of TS $\mathrm{F}+\mathrm{SSF}+\mathrm{PSF}+\mathrm{AASF}+\mathrm{SISF}+\mathrm{ASF}+\mathrm{MTSF}+; \% \mathrm{BF}=$ body bat percentage.

\section{Measurement of technical error (MTE)}

The measure of intra-rater MTE provides the rater precision and it should be used as follows: the same rater performs the collection on different days, using the same material, unit of measure and conditions (Norton and Olds, 2000).

The method of differences was used to obtain the MTE, which is expressed by the standard deviation of repeated measurements (Pederson and Gore, 2000). This deviation is the degree of value dispersion from the average. The MTE calculation was divided into four steps, which are described below to provide a better understanding of the method.

\section{MTE intra-rater calculator}

The MTE intra-rater calculation considered the results of skin fold measurements of 20 volunteers (12 men and 8 women) on the first and second days of evaluation, according to Norton and Olds (2005):

First stage: The difference between the 1st and 2 nd measurements was determined for each skin fold of all 20 volunteers.

Second stage: The obtained deviations were squared.

Third stage: The results of the second stage were summed $\left(\Sigma \mathrm{d}^{2}\right)$ and applied to obtain the absolute MTE.

$$
\text { MTE absolute }=\sqrt{\frac{\sum d^{2}}{2 n}}
$$

where:

$\Sigma \mathrm{d}^{2}=$ sum of deviations squared;
$\mathrm{N}=$ number of volunteers measured;

$\mathrm{I}=$ as many deviations as there are.

Fourth stage: The absolute MTE was modified into relative MTE to obtain the error expressed as a percentage. It required the calculation of the average value of the variable (AVV), as follows: the arithmetic average between the 1 st and 2 nd measurements of each volunteer was obtained for the same skin fold, that is, the measurement taken on the first and second day of each volunteer was added and divided by two, generating the average of this fold. This procedure was done for each of the 20 volunteers and the 20 average values obtained were summed and divided by 20 (total volunteers).

$\operatorname{MTE}($ relative $)=\frac{M T E}{A V V} \times 100$

where:

$\mathrm{MTE}=$ Measurement of technical error, expressed in $\%$; $\mathrm{AVV}=$ Average value of the variable.

\section{MTE classification}

The lower the MTE obtained, the better the accuracy of the rater when conducting the measurement. According to Norton and Olds (2000), the acceptable values for the intra-evaluative MTE in the collection of skin folds are: $7.5 \%$ and $5 \%$ for beginner and experienced anthropometrists, respectively.

\section{Statistical analyses}

Data were analyzed using BioState 20075.0 and Excel 2010 software. To display the anthropometric characteristics of the participants, data were presented as average, standard deviation (SD), standard error of the average (SEA), and minimum-maximum amplitude. For all statistical procedures, the significance level of $\mathrm{p} \leq 0.05$ was used. The normality of the fat percentage found with the WCS Dual Hand and Lange skinfold calipers were verified by the Kolmogorov-Smirnov test. The fat percentage obtained with the equation of Jackson and Pollock (1978) of 3 skin folds for men, and the equation of Jackson et al. (1980) of 3 skin folds for women were the only ones that did not present normality. The comparison was performed through the Wilcoxon test for paired data, and for both cases the p-value was lower than 0.0001 .

To correct the values found with the WCS Dual Hand skinfold caliper, a simple linear regression model was developed through the ordinal least squares method for each of the eight equations considering the $\%$ fat obtained with the Lange skinfold caliper as variable $Y$ and the $\%$ of fat obtained with the WCS skinfold caliper as variable $\mathrm{X}$, using the calculations below: 
$Y=b_{0}+b_{1}^{*} X$

which in this case can be represented as:

Lange $=b_{0}+b_{1}^{*} W C S$

with values of $b_{0}$ and $b_{1}$ determined as follows:

$b_{1}=\frac{\sum X Y-\frac{\sum X \sum Y}{n}}{\sum X^{2}-\frac{\left(\sum X\right)^{2}}{n}}$

$b_{0}=\frac{\sum Y}{n}-b_{1} \frac{\sum X}{n}$

where:

$\mathrm{n}=$ number of individuals analyzed;

$\mathrm{X}=\%$ of fat estimated with the WCS skinfold caliper; $\mathrm{Y}=\%$ of fat estimated with the Lange skinfold caliper.

This procedure was performed for each of all eight formulas of Jackson and Pollock (1978), Jackson et al. (1980), Durnin and Womersley (1974), and Petroski (1995), and the correction equations were obtained for both male and female participants.

\section{Results}

Table 1 shows the mean, standard deviation, maximum and minimum values for age, body mass, height and BMI of 112 undergraduate students who were included in the study. Data were compared between the groups, men presented higher values in relation to women in all variables, with significant differences. The p-value was 0.018 for age, 0.000 for body mass, 0.000 for height, and 0.000 for BMI.

Table 2 shows the comparison between the average values of skin fold thickness of 54 men, measured with the WCS Dual Hand and Lange skinfold calipers. The average values obtained with the Lange skinfold caliper are significantly higher than those found with the WCS Dual Hand skinfold caliper. A difference was observed in triceps, chest, suprailiac, and calf skin folds. The average values obtained with the Lange skinfold caliper are significantly higher than those found with the WCS Dual Hand skinfold caliper for the measurements of triceps, pectoral, suprailiac, and calf skin folds.

Table 3 shows the correction equations of $\%$ BF values of male participants, derived from the measurements of skin fold thickness with the Lange and WCS Dual Hand skinfold calipers.

Table 4 shows the comparison between the average values of skin fold thickness of 58 women, measured with the WCS Dual Hand and Lange skinfold calipers. The average values obtained with the Lange skinfold caliper are significantly higher than those found with the WCS Dual Hand skinfold caliper for all the measures analyzed.

The corrections equations for the correction of $\% \mathrm{BF}$ values female, derived from measurements of skin fold thickness, measured with adipometers Lange and WCS Dual Hand are presented in Table 5.

Table 1. Description of the participants - 112 students.

\begin{tabular}{|c|c|c|c|c|c|c|}
\hline \multirow{2}{*}{ Variables } & \multicolumn{3}{|c|}{ Male $(n=54)$} & \multicolumn{3}{|c|}{ Female $(n=58)$} \\
\hline & Mean \pm SD & Maximum & Minimum & Mean \pm SD & Maximum & Minimum \\
\hline Age (years) & $27.6 \pm 7.9$ & 51 & 18 & $24.9 \pm 5.8$ & 44 & 18 \\
\hline Body Mass (kg) & $75.5 \pm 10.6$ & 106 & 58 & $60.4 \pm 7.4$ & 77.2 & 45.8 \\
\hline Height (cm) & $174 \pm 0.05$ & 192 & 163 & $163 \pm 0.06$ & 176 & 149 \\
\hline BMI $\left(\mathrm{kg} / \mathrm{m}^{2}\right)$ & $24.8 \pm 2.7$ & 29.9 & 19.8 & $22.9 \pm 2.1$ & 27.3 & 18.6 \\
\hline
\end{tabular}

BMI: body mass index; Mean \pm SD: Mean \pm Standard deviation.

Table 2. Comparison between the thickness of skin folds, estimated by the Lange and WCS Du al Hand plicometers, measured in 54 men who were part of the sample.

\begin{tabular}{|c|c|c|c|c|}
\hline Skin folds (mm) & Lange (Mean \pm SD) & WCS dual hand (Mean \pm SD) & Difference (mm) & P-value \\
\hline $\mathrm{BSF}$ & $5.2 \pm 2.2$ & $4.5 \pm 2.4$ & 0.7 & 0.060 \\
\hline TSF & $11.3 \pm 5.8$ & $9.1 \pm 5$ & 2.2 & 0.022 \\
\hline $\mathrm{SSF}$ & $19.6 \pm 8.6$ & $17 \pm 8.6$ & 2.6 & 0.061 \\
\hline PSF & $12.1 \pm 6.1$ & $10.1 \pm 5.6$ & 2.0 & 0.041 \\
\hline AASF & $12.5 \pm 7.5$ & $10.4 \pm 7.1$ & 2.1 & 0.079 \\
\hline SISF & $20.8 \pm 10.4$ & $16.2 \pm 10.5$ & 4.6 & 0.013 \\
\hline ASF & $23 \pm 12.2$ & $20.4 \pm 13.1$ & 2.6 & 0.149 \\
\hline MTSF & $15 \pm 7.1$ & $12.9 \pm 6.7$ & 2.1 & 0.065 \\
\hline $\mathrm{CSF}$ & $8.6 \pm 4.2$ & $7 \pm 3.4$ & 1.6 & 0.015 \\
\hline
\end{tabular}

BSF: biceps; TSF: triceps; SSF: subscapular; PSF: pectoral; AASF: average axillary; SISF: suprailiac; ASF: abdominal; MTSF: medial thigh; CSF: calf; Mean \pm SD: Mean \pm Standard deviation. 
Table 3. Regression equations for correcting the percentage of fat estimated by skin fold thickness measured with plicometer WCS Dual Hand for 54 men.

\begin{tabular}{cccc}
\hline Variables & Equation for correction of \% BF & $\mathbf{R}^{2}$ & P-value \\
\hline D \& W & $\% \mathrm{BF}=6.5592269+0.8243132 * \% \mathrm{BF}$ WCS & 0.913 & 0.000 \\
Petroski & $\% \mathrm{BF}=3.8090510+0.9384101 * \% \mathrm{BF}$ WCS & 0.949 & 0.000 \\
J \& P 3 & $\% \mathrm{BF}=2.6884021+0.9410678 * \% \mathrm{BF}$ WCS & 0.946 & 0.000 \\
J, P \& W 7 & $\% \mathrm{BF}=3.3478433+0.9347317 * \% \mathrm{BF}$ WCS & 0.961 & 0.000 \\
\hline
\end{tabular}

D \& W: Durnin \& Womersley (1974); Petroski: Petroski (1995); J \& P 3: Jackson \& Pollock (1978) 3 skin folds; J, P \& W 7: Jackson \& Pollock (1978) 7 skin folds; \% BF: Percentage of body fat; $\mathrm{R}^{2}$ : coefficient of determination; P-value: estimation error.

Table 4. Comparison between the thicknesses of skin folds, estimated by plicometers Lange and WCS Dual Hand, measured in 58 women who were part of the sample.

\begin{tabular}{ccccc}
\hline Skin folds $(\mathbf{m m})$ & Lange $($ Mean \pm SD) & WCS Dual Hand (Mean \pm SD) & Difference (mm) & P-value \\
\hline BSF & $10.3 \pm 4.2$ & $7.7 \pm 3.2$ & 2.6 & 0.000 \\
TSF & $22.1 \pm 5.4$ & $17.6 \pm 5.4$ & 4.5 & 0.000 \\
SSF & $21.9 \pm 6.8$ & $19 \pm 7$ & 2.9 & 0.014 \\
PSF & $13.9 \pm 5.5$ & $11.8 \pm 5$ & 2.1 & 0.016 \\
AASF & $15.5 \pm 7.3$ & $12.5 \pm 7$ & 3.0 & 0.013 \\
SISF & $25.4 \pm 7.7$ & $20 \pm 7.3$ & 5.4 & 0.000 \\
ASF & $26.3 \pm 8.3$ & $23 \pm 7.7$ & 3.3 & 0.013 \\
MTSF & $35.3 \pm 8.3$ & $31.8 \pm 9.3$ & 3.5 & 0.018 \\
CSF & $19.4 \pm 5.9$ & $16.3 \pm 5.2$ & 3.1 & 0.001 \\
\hline
\end{tabular}

BSF: biceps; TSF: triceps; SSF: subscapular; PSF: pectoral; AASF: average axillary; SISF: suprailiac; ASF: abdominal; MTSF: medial thigh; CSF: calf; Mean \pm SD: Mean \pm Standard deviation.

Table 5. Regression equations for correcting the percentage of fat estimated by skin fold thickness measured with WCS Dual Hand plicometer for 58 women.

\begin{tabular}{cccc}
\hline Variables & Equation for correction of \% BF & $\mathbf{R}^{\mathbf{2}}$ & P-Value \\
\hline D \& W & $\% \mathrm{BF}=8.8446522+0.8224759 * \% \mathrm{BF}$ WCS & 0.893 & 0.000 \\
Petroski & $\% \mathrm{BF}=6.9850725+0.8184568 * \% \mathrm{BF}$ WCS & 0.910 & 0.000 \\
J, P \& W 3 & $\% \mathrm{BF}=7.8683214+0.8533205 * \% \mathrm{BF}$ WCS & 0.907 & 0.000 \\
J, P \& W 7 & $\% \mathrm{BF}=6.1462522+0.9696753 * \% \mathrm{BF}$ WCS & 0.830 & 0.000 \\
\hline
\end{tabular}

D\&W: Durnin \& Womersley (1974); Petroski: Petroski (1995); J, P \& W: Jackson et al. (1980) 3 skin folds; J, P \& W 7: Jackson et al. (1980) 7 skin folds;

$\% \mathrm{BF}$ : Percentage of body fat; $\mathrm{R}^{2}$ : coefficient of determination; P-value: estimation error.

Table 6. Presentation of the MTE intra-evaluator, tested with 20 participants of the research (12 men and 8 women).

\begin{tabular}{cccccccccc}
\hline Skin folds & BSF & TSF & SSF & PSF & AASF & SISF & ASF & MTSF & CSF \\
\hline MTE relative & $0.99 \%$ & $1.93 \%$ & $3.05 \%$ & $2.34 \%$ & $2.07 \%$ & $3.07 \%$ & $3.64 \%$ & $3.04 \%$ & $1.77 \%$ \\
MTE average & $2.43 \%$ & & & & & & & & \\
MTE experient & $5.0 \%$ & & & & & & & \\
MTE beginner & $7.5 \%$ & & & & & & & \\
\hline
\end{tabular}

MTE relative: Intra-rater error; MTE average: Average of the intra-rater errors of the nine skin folds collected; Experient MTE: Intra-rater error acceptable for experienced anthropometrists; Initiating MTE: Intra-rater error acceptable for beginner anthropometrists; BSF: biceps; TSF: triceps; SSF: subscapular; PSF: pectoral; AASF: average axillary; SISF: suprailiac; ASF: abdominal; MTSF: medial thigh; CSF: calf.

Intra-rater technical error of measurement was analyzed and presented high acceptance of measures collected by the anthropometrist of this study; the acceptance criterion adopted for experienced anthropometrists was $\leq 5.0 \%$, and $\leq 7.0 \%$ for beginning anthropometrists. These results are presented in Table 6.

After observing significant differences in most skin folds collected, correction equations were created for each of the three formulas used in the study for both sexes (Tables 3 and 5). The average results found with the Lange and WCS Dual Hand skinfold calipers with the corrected values obtained from the WCS Dual Hand skinfold caliper after being calculated in the correction equations to estimate the relative fat percentage for men and women, illustrated in Figures 1 and 2, respectively.

\section{Discussion}

Several methods to estimate body composition have already been validated and proven effective, but the simplicity and the higher level of acceptance by the evaluated people, as it is a non-invasive low-cost 


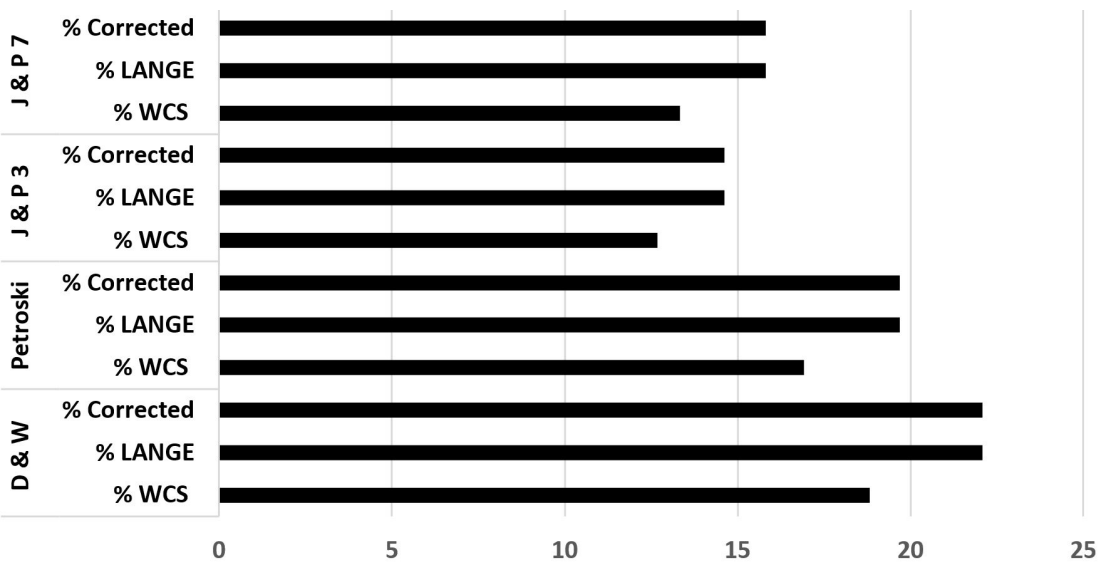

Figure 1. Averages percentages of fat found by plicometers Lange, WCS and calculated with the correction equation, for relative values of the corporal fat obtained through the formulas proposed by Durnin and Womersley (1974); Petroski (1995); Jackson and Pollock (1978) 3 skin folds and Jackson and Pollock (1978) 7 skin folds for men. D \& W: Equation Durnin and Womersley (1974); Petroski: Equation Petroski (1995); J \& P 3: Equation Jackson and Pollock (1978) 3 skin folds; J \& P 7 Equation Jackson and Pollock (1978) 7 skin folds; \% corrected: Average value found by applying the percentage of fat obtained by plicometer WCS dual hand, in the correction equation; Lange\%: Average percentage of fat obtained with the compass Lange; WCS\%: average fat percentage obtained with plicometer WCS.

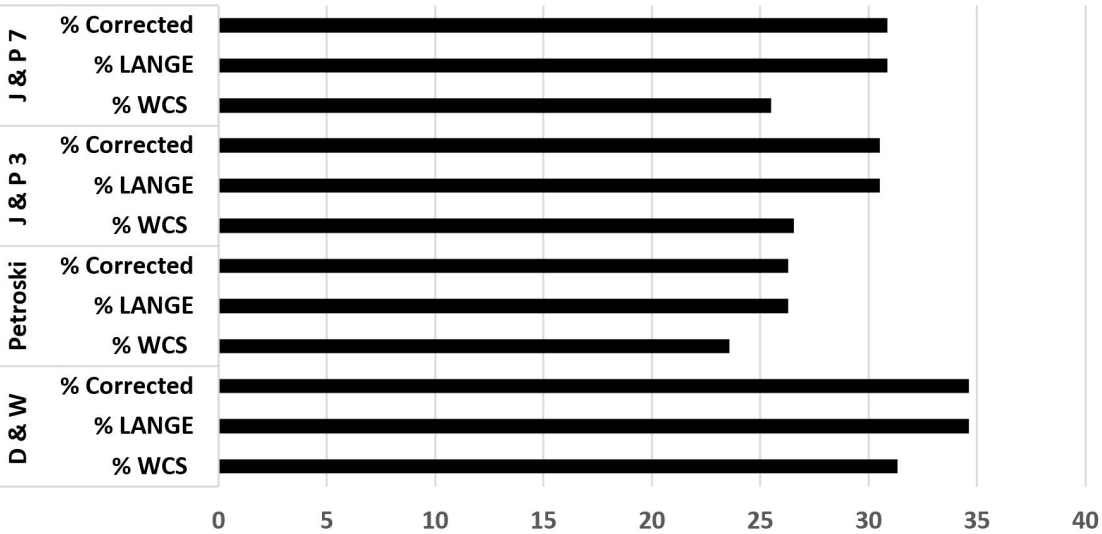

Figure 2. Averages percentages of fat found by plicometers Lange, WCS and calculated with the correction equation, for relative values of the corporal fat obtained through the formulas proposed by Durnin and Womersley (1974); Petroski (1995), Jackson et al. (1980), and Jackson et al. (1980) for women. D \& W: Equation Durnin and Womersley (1974); Petroski: Equation Petroski (1995); J, P \& W 3: Equation Jackson et al. (1980) 3 skin folds; J, P \& 7 Equation Jackson et al. (1980) 7 skin folds; \% corrected: Average value found by applying the percentage of fat obtained by plicometer WCS dual hand, in the correction equation; Lange \%: Average percentage of fat obtained with the Lange plicometer; WCS\%: average fat percentage obtained with plicometer WCS.

technique, have made skin fold the most accepted method by health professionals to date (Rodrigues et al., 2001; Lintsi et al., 2004; Guedes, 2006).

Studies comparing different methods of body fat calculation show that the use of skin folds has a strong correlation with portable ultrasonography and electric bioimpedance (Neves et al., 2013), besides presenting approximate results with more analysis means such as hydrostatic weighing and DEXA (Rodrigues et al., 2001; Lintsi et al., 2004).

Although it shows a high correlation with the total amount of body fat, the results obtained from skin folds may have their accuracy compromised, that is, the values found through this technique may differ from the actual values, since they may be affected by factors such as difference of adipose tissue compressibility, the evaluated hydration status, muscle mass quantity, increased bone density, age and sex of the evaluated individual, as well as the way the skinfold caliper was handled by the rater, as well as the equipment calibration (Lorenzo et al., 2000; Gore et al., 2000; Lohman, 1981).

Therefore, safe, practical and valid instruments should be used to determine and identify the changes that may occur in body composition (Deminice and Rosa, 2009).

It should also be noted that different anthropometric equations have been developed, each targeted to a different group (Ellis, 2001), respecting factors like sex, ethnicity, and age (Rezende et al., 2007), which, when applied to 
other populations or situations can produce large errors (Eliakim et al., 2000). For Okano et al. (2008), many of the equations used in Brazil were developed using skinfold calipers that differ from those frequently used in Brazil, thus it may increase the probability of error at the end of the calculations. Therefore, the selection of appropriate equipment and methodology is of paramount importance for the professionals to obtain solid results according to their goals.

When specifically addressing the equations of body density estimation, four of the most commonly used were selected for this study, as follows: Jackson et al. (1980), Jackson and Pollock (1978), and Durnin and Womersley (1974) - all international equations, as well as the formula created by Petroski (1995), developed in Brazil.

The equations proposed by Jackson and Pollock (1978) were developed with a sample of 308 male participants, aged 18 to 61 years. The formula for women, developed by Jackson et al. (1980), had a sample of 249 female participants, aged 18 to 55 years. Durnin and Womersley (1974), when analyzing 209 men and 272 women, developed several equations stratifying the sample according to age, but the authors present general calculations for both sexes, which were used in this study. Petroski (1995) evaluated 304 men and 281 women, aged 18 to 66 years, and 18 to 51 years, respectively.

Considering the above, this study aimed to propose regression equations to correct the $\%$ fat values obtained with the WCS Dual Hand skinfold caliper, using the Lange skinfold caliper as a reference, which is widely used in many existing anthropometric equations.

As indicated in Tables 2 and 4, skin folds (BSF, SSF, AASF, MTSF and ASF) for males did not show statistically significant differences. Regarding the female participants in particular, for all skin folds, the $\mathrm{p}$-value was less than 0.05 , showing a significant difference between the Lange and the WCS Dual Hand skinfold calipers. However, some skin fold values collected from the male sample (TSF, SISF, PSF, and CSF) and all the folds from the female group had higher averages for the Lange skinfold caliper $(p=0.05)$ when compared with the WCS Dual Hand skinfold caliper, which can be attributed to a difference in the contact surface of both skinfold calipers, considering the Lange caliper has a contact area of less than $3 \mathrm{~mm}^{2}$ and the WCS Dual Hand caliper, $5 \mathrm{~mm}^{2}$, or possible intra-rater errors. However, the intra-evaluative MTE for the anthropometrist of this study presented the average of $2.43 \%$ of the nine folds collected in the study, indicating acceptance and great repeatability of the measurements. Thus, it is believed that the differences found in Table 2 and 4 are not attributed to the rater.

However, compressibility of the subcutaneous tissue and skin thickness are two variables that can affect skin fold measurements, as two identical thickness values of fat tissue may contain significantly different concentrations of fat (Clarys et al., 1987).

Okano et al. (2008) found similar results to this study by comparing skin fold values obtained with the Lange skinfold caliper to values obtained with the Cescorf skinfold caliper in a sample of 259 men. The authors concluded that, in order to conduct the assessment with the Cescorf skinfold caliper using the formulas validated with the Lange skinfold caliper, it is necessary to use correction equations to reduce the difference between the measurements performed with both skinfold calipers.

Regarding the assessed equations, Tables 3 and 5 were proposed as a result of measurements with the Lange skinfold caliper. Therefore, the acceptance of these proposed correction equations aims to minimize the systematic error caused by differences in the measurement scale of the skinfold calipers. A limitation of this study was the inability to eliminate measurement errors of the rater, which may have impacted the results. The values of the estimated \% BF are affected by the type of skinfold caliper, due to factors such as measurement range, contact surface, and mechanics, so the skinfold caliper to be used should be the one from which the prediction equation was originated (Okano et al., 2008).

Finally, the results obtained in this study show significant differences in the percentage of body fat estimated with the WCS Dual Hand and Lange skinfold calipers using the equations of Jackson and Pollock (1978), Jackson et al. (1980), Durnin and Womersley (1974), and Petroski (1995) for both male and female participants. Thus, the authors of this study suggest the use of equations presented in this study to correct the relative body fat estimated with the WCS Dual Hand skinfold caliper, whenever the use of the Lange skinfold caliper is not available, in order to minimize the difference between the skinfold calipers.

\section{References}

Carvalho ABR, Pires CS No. Composição corporal através dos métodos de pesagem hidrostática e impedância biolétrica em universitários. Rev bras cineantropom desempenho hum. 1999; 1(1):18-23.

Clarys JP, Martin AD, Drinkwater DT, Marfell-Jones MJ. The skin fold: myth and reality. Journal of Sports Sciences. 1987; 5(1):3-33. PMid:3430678. http://dx.doi.org/10.1080/02640418708729760.

Conterato EV, Vieira EL. Composição corporal em universitários utilizando dobras cutâneas e bioimpedância elétrica: um método comparativo. Disciplinarium Scientia. Série Ciên Biol Saúde. 2001; 2(1):125-37.

Cyrino ES, Okano AH, Glaner MF, Romanzini M, Gobbo LA, Makoski A, Bruna N, Melo JC, Tassi GN. Impacto da utilização de diferentes compassos de dobras cutâneas para a análise da composição corporal. Rev Bras Med Esporte. 2003; 9(3):21-8.

Deminice R, Rosa FT. Pregas cutâneas vs impedância bioelétrica na avaliação da composição corporal de atletas: 
uma revisão crítica. Rev bras cineantropom desempenho hum. 2009; 11(3):334-40.

Durnin JVGA, Womersley J. Body fat assessed from total body density and its estimation from skin fold thickness: Measurements on 481 men and women aged from 16 to 72 years. Br J Nutr. 1974; 32(1):77-97. PMid:4843734. http:// dx.doi.org/10.1079/BJN19740060.

Eliakim A, Ish-Shalom S, Giladi A, Falk B, Constantini N. Assessment of body composition in ballett dancers: correlation among anthropometric measurements, bioelectrical impedance analysis, and dual-energy X-ray absorptiometry. Int J Sports Med. 2000; 21(8):598-601. PMid:11156282. http://dx.doi. org/10.1055/s-2000-8489.

Ellis KJ. Selected body composition methods can be used in field studies. J Nutr. 2001; 131(5):1589S-95S. PMid:11340123.

Gil AC. Como elaborar projetos de pesquisa. 4. ed. São Paulo: Atlas; 2002.

Gore CJ, Carlyon RG, Franks SW, Woolford SM. Skin fold thickness varies directly with spring coefficient and inversely with jaw pressure. Med Sci Sports Exerc. 2000; 32(2):5406. PMid:10694144. http://dx.doi.org/10.1097/00005768200002000-00042.

Guedes DP. Recursos antropométricos para análise da composição corporal. Rev Bras Educ Fís Esporte. 2006; 20:115-9.

Guedes DP. Procedimentos clínicos utilizados para análise da composição corporal. Rev bras cineantropom desempenho hum. 2013; 15(1):113-29. http://dx.doi.org/10.5007/1980$0037.2013 \mathrm{v} 15 \mathrm{n} 1 \mathrm{p} 113$.

Heyward V. ASEP methods recommendation: body composition assessment. J Exerc Physiol. 2001; 4(4):1-12.

Jackson AS, Pollock ML, Ward A. Generalized equations for predicting body density of women. Med Sci Sports Exerc. 1980; 12(3):175-81. PMid:7402053. http://dx.doi. org/10.1249/00005768-198023000-00009.

Jackson AS, Pollock ML. Generalized equations for predicting body density of men. Br J Nutr. 1978; 40(3):497-504. PMid:718832. http://dx.doi.org/10.1079/BJN19780152.

Lintsi M, Kaarma H, Kull I. Comparison of hand-to-hand bioimpedance and anthropometry equations versus dualenergy X-ray absorptiometry for the assessment of body fat percentage in 17-18-year-old conscripts. Clin Physiol Funct Imaging. 2004; 24(2):85-90. PMid:15056180. http://dx.doi. org/10.1111/j.1475-097X.2004.00534.X.

Lohman TG, Roche AF, Martorell R. Anthropometric standardization reference manual. Champaign: Human Kinectics Books; 1988.

Lohman TG. Skin folds and body density and their relation to body fatness: a review. Human Biology. 1981; 53(2):181-225. PMid:7239496.

Lorenzo A, Bertini I, Iacopino L, Pagliato E, Testolin C, Testolin G. Body composition measurement in highly trained male athletes: a comparison of three methods. J Sports Med Phys Fitness. 2000; 40(2):178-83. PMid:11034440.
Melo LGM, Favaris FM, Pastore JCF, Costa FCH, Ferreira CAA. Identificação de variáveis intervenientes no cálculo do erro técnico de medida (ETM). Coleç Pesq Educ Fís. 2012; 11(2):105-12.

Neves EB, Ripka WL, Ulbricht L, Stadnik AMW. Comparison of the fat percentage obtained by bioimpedance, ultrasound and skin folds in young adults. Rev Bras Med Esporte. 2013; 19(5):323-7. http://dx.doi.org/10.1590/S1517-86922013000500004.

Norton K, Olds T. Antropométrica. Argentina: Biosystem Servicio Educativo; 2000.

Norton K, Olds T. Antropométrica. Porto Alegre: Artmed; 2005.

Okano AH, Carvalho FO, Cyrino ES, Gobbo LA, Romanzini M, Glaner MF, Reichert FF, Avelar A. Utilização do adipômetro CESCORF para estimativa da gordura corporal relativa a partir de equações validadas com o adipômetro Lange. Rev Educ Fís. 2008; 19(3):431-6.

Pederson D, Gore C. Error en la medición antropométrica. In: Norton K, Olds T, editors. Antropométrica. Argentina: Biosystem Servicio Educativo; 2000. p. 71-86.

Perini TA, Oliveira GLD, Ornellas JDS, Oliveira FPD. Cálculo do erro técnico de medição em antropometria. Rev Bras Med Esporte. 2005; 11(1):81-5. http://dx.doi.org/10.1590/S151786922005000100009

Petroski ÉL. Desenvolvimento e validação de equações generalizadas para a estimativa da densidade corporal em adultos [dissertation]. Santa Maria: Centro de Educação Física e Desportos, Universidade Federal de Santa Maria; 1995.

Rezende F, Rosado L, Franceschinni S, Rosado G, Ribeiro R, Marins JC. Revisão crítica dos métodos disponíveis para avaliar a composição corporal em grandes estudos populacionais e clínicos. Arch Latinoam Nutr. 2007; 57(4):327-34. PMid:18524316.

Rodrigues MN, Silva SC, Monteiro WD, Farinatti PTV. Estimativa da gordura corporal através de equipamentos de bioimpedância, dobras cutâneas e pesagem hidrostática. Rev Bras Med Esporte. 2001; 7(4):125-31. http://dx.doi.org/10.1590/ S1517-86922001000400003.

Siri WE. The gross composition of the body. Adv Biol Med Phys. 1956; 4:239-80. PMid:13354513. http://dx.doi.org/10.1016/ B978-1-4832-3110-5.50011-X.

Souza WC, Luis PGM, Reiser FC, Souza WB, Lima VA, Marcos ABM, Grzelczak MT. Relação entre o índice de adiposidade corporal, circunferência do pescoço e índice de massa corporal em mulheres sedentárias. RBONE. 2014; 8(48):159-64.

Sundgot-Borgen J, Nanna L. Sundgot-Borgen J, Meyer NL, Lohman TG, Ackland TR, Maughan RJ, Stewart AD, Müller W. How to minimise the health risks to athletes who compete in weight-sensitive sports review and position statement on behalf of the Ad Hoc Research Working Group on Body Composition, Health and Performance, under the auspices of the IOC Medical Commission. Br J Sports Med. 2013; 47(16):1012-22. PMid:24115480. http://dx.doi.org/10.1136/ bjsports-2013-092966. 